\title{
BEHAVIOUR OF PAVEMENT QUALITY CONCRETE WITH RECLAIMED ASPHALT PAVEMENT AGGREGATES
}

\author{
Panditharadhya B J $\mathbf{J}^{1}$, Reshma E $\mathbf{K}^{2}$, Suhas $\mathbf{R}^{3}$ \\ ${ }^{I}$ Assistant Professor, VijayaVittala Institute of Technology, VisvesvarayaTechnological University, Karnataka, India, \\ pandith23@gmail.com \\ ${ }^{2}$ Assistant Professor, DayanandaSagar College of Engineering, VisvesvarayaTechnological University, Karnataka, \\ India, reshu.ek@gmail.com \\ ${ }^{3}$ Assistant Professor, DayanandaSagar College of Engineering, Visvesvaraya Technological University, Karnataka, \\ India, suhasr.dsce@gmail.com
}

\begin{abstract}
Concrete is the basic material in all construction works and coarse aggregates constitute more than 50\% of the mix. But the procurement and generation of natural aggregates is getting difficult day by day because of lack of natural source and environmental effects. In search of alternative for natural aggregates, lead to the usage of Reclaimed Asphalt Pavement aggregates, which are produced abundantly due to replacement of Flexible Pavements with Rigid Pavements in India. This study is taken up to determine the variation of different properties of strength and mainly durability of concrete pavements with natural aggregates and RAP aggregates. The cubes will be casted and tested for Strength and Flexural Strength is also determined by casting beams. The results can be analyzed to identify the importance of RAP aggregates for its effective and efficient usage for present scenario of India. The RAP Aggregates are procured from NICE, Bangalore. And it is checked for the effective utilization in Concrete Pavements. RAP aggregates are replaced with Natural Aggregates by 100\%, 75\%, 50\% and 25\% and evaluated. Also the fatigue models are developed by testing the beams under repeated loadings by considering stress ratio of 65\%, 75\% and $85 \%$.
\end{abstract}

Keywords: Concrete, Fatigue Models, Flexible Pavements, Flexural Strength, Natural Aggregates, Reclaimed Asphalt Pavement (RAP), Repeated Loadings, Rigid Pavements, Stress Ratio.

\section{INTRODUCTION}

The highway construction industry has made rapid strides in the field of innovative technologies up-gradation and adaption. With increasing traffic volumes and an increased demand for innovative rehabilitation and repair of the aging transportation infrastructure, there is scope for new concepts that prove to be viable and cost effective solution for pavement rehabilitation. Newer materials have been tried with a lot of emphasis on optimizing life cycle cost and minimizing the pavement distresses.Each year, the highway industry produces over several million tons of reclaimed asphalt pavement (RAP) through the rehabilitation and construction of the nation's roads. Using RAP as aggregate in Portland cement concrete pavement $(\mathrm{PCCP})$ is one attractive application for furtheruse of this recyclable material. Earlier research has demonstrated the feasibility of creating concrete with RAP aggregate; however, prior studies focus on mechanical properties of the material. This project will further distinguish the properties of this material and draw conclusions on the concrete's aptness for use as a pavement in road construction. This project work encompasses the development of RAP in PCCP mixtures that will subsequently move forward for a more thorough evaluation of their material properties. The mixing experiment and preliminary testing phases of this project provided information to draw a number of conclusions about the appropriateness of RAP aggregate in PCCP.A feasible model with $75 \%$ natural aggregate and $25 \%$ RAP aggregate has shown considerable strength properties and hence can be opted for pavement for surface course.

\section{LITERATURE SURVEY}

${ }^{[1]}$ Delwar, Fahmy, and Taha of the University of Washington and Sultan QaboosUniversity performed one of the first studies on this "green" concrete in 1997. The main goals of their research entailed an investigation on the feasibility of using RAP as aggregate in Portland cement concrete (PCC), and the determination of key material properties and characteristics of the alternative material. RAP millings for use in the concrete test mixtures were obtained from an asphalt producer in Spokane, Washington. The research team processed the material through a set of sieves, removing any aggregate larger than $3 / 4-$ inch and fractionating the material on the No. 4 sieve. Standard concrete sand and gravel, as well as type I/II cement were purchased from a company in Moscow, Idaho for use in the study. Mixes containing 10 different aggregate arrangements with two different water-cement (w/c) ratios were tested for compressive strength and stress-strain characteristics. Data on the slump, air content, and unit weight of the wet concrete were also recorded. 
${ }^{[2]}$ Huang, Shu, and Li of the University of Tennessee and Louisiana State University expanded the available information on concrete containing RAP with their work in 2005. The

objective of their study was to further research the effect of the inclusion of RAP aggregates on the toughness and brittle failure behavior of Portland cement concrete. The study hypothesized that the fine layer of asphalt coating the individual pieces of aggregate protects the particles from breakage and facilitates the increased dissipation of energy in the event of a crack.

${ }^{[3]}$ Huang \&Shu, After Huang and Shu's initial research on RAP concrete, they performed additional testing on specimens that included admixtures to help improve the performance of the material (Huang, Shu, \& Li, 2005). Both silica fume and a high-range water reducing agent (HRWRA) were added to help reduce the loss of strength accrued by the use of the RAP aggregate. As in prior studies, several mix designs using different percentages of coarse and/or fine RAP aggregate $(10,30,50$, or 100 percent by weight) were used as a replacement for virgin aggregate.

${ }^{[4]}$ Hossiney, In 2008, Nabil Hossiney from the University of Florida worked with the Florida Department of Transportation (FDOT) to study the performance of RAP concrete used in a rigid pavement application. In their study, four concrete mixtures containing reclaimed asphalt pavement were evaluated in a laboratory setting. The tested material properties were then used to create a finite element model to assess how the concretes would behave as a pavement under typical Florida roadway conditions. The natural aggregate for the mixing experiment consisted of a porous limestone coarse rock and a standard silica sand fine material. The mixtures evaluated in the study included mix designs containing $0,10,20$, and 40 percent RAP aggregate. Laboratory test results indicated that the compressive strength, splitting tensile strength, flexural strength, and elastic modulus of the hardened material were inversely related to the amount of RAP in the mix; these material properties all decreased as the RAP replacement rate was increased.

\section{PRESENT INVESTIGATIONS}

The physical properties of materials used in the experiments are determined with the standard test procedures as per Indian Standard (IS) Codes. Test results are tabulated as given below,

Table - 3.1: Properties of Cement

\begin{tabular}{|c|c|c|c|}
\hline $\begin{array}{l}\text { SI. } \\
\text { N } \\
\text { o. }\end{array}$ & Characteristics & Results & $\begin{array}{c}\text { As per } \\
\text { IS:12269- } \\
1987 \\
\end{array}$ \\
\hline 1 & Normal Consistency (\%) & 32 & - \\
\hline 2 & Initial setting time(minutes) & 30 & $30 \mathrm{~min}$ \\
\hline 3 & Final setting time (minutes) & 460 & $600 \max$ \\
\hline 4 & Specific gravity & 3.15 & 3.15 \\
\hline
\end{tabular}

Table-3.2:Properties of M Sand

\begin{tabular}{|c|c|c|}
\hline Sl. No. & Characteristics & Value \\
\hline 1. & Specific gravity & 2.73 \\
\hline 2. & Water absorption & $1.5 \%$ \\
\hline 3. & Moisture content $(\%)$ & $2.2 \%$ \\
\hline 4. & Fineness modulus & 3.866 \\
\hline 5. & Grading zone & Zone II \\
\hline
\end{tabular}

Table-3.3:Properties of Coarse aggregates

\begin{tabular}{|c|c|c|c|c|}
\hline No. & Tests & Results & Requirements & $\begin{array}{c}\text { IS- } \\
\text { Codes }\end{array}$ \\
\hline 1 & $\begin{array}{l}\text { Specific } \\
\text { gravity }\end{array}$ & 2.73 & - & $\begin{array}{l}\text { IS-2386 } \\
\text { Part III }\end{array}$ \\
\hline 2 & $\begin{array}{l}\text { Crushing } \\
\text { Value }\end{array}$ & $28.1 \%$ & $\begin{array}{l}\text { shall not } \\
\text { exceed } 45 \% \\
\text { non-wearing } \\
\text { surfaces, } 30 \\
\text { percent for } \\
\text { wearing } \\
\text { surfaces }\end{array}$ & $\begin{array}{c}\text { IS-2386 } \\
\text { Part IV }\end{array}$ \\
\hline 3 & $\begin{array}{l}\text { Abrasion } \\
\text { Value }\end{array}$ & $27.4 \%$ & $\begin{array}{l}\text { For aggregates } \\
\text { to be used in } \\
\text { concrete for } \\
\text { wearing } \\
\text { surfaces not } \\
\text { exceed } 30\end{array}$ & $\begin{array}{l}\text { IS-2386 } \\
\text { Part IV }\end{array}$ \\
\hline 4 & $\begin{array}{l}\text { Impact } \\
\text { Value }\end{array}$ & $27.0 \%$ & $\begin{array}{lr}\text { shall } & \text { not } \\
\text { exceed } & 30 \\
\text { percent } & \text { by } \\
\text { weight } & \text { for } \\
\text { concrete } & \text { for } \\
\text { wearing } & \\
\text { surfaces } & \end{array}$ & $\begin{array}{l}\text { IS-2386 } \\
\text { Part IV }\end{array}$ \\
\hline 5 & $\begin{array}{c}\text { Water } \\
\text { Absorption }\end{array}$ & $0.45 \%$ & - & $\begin{array}{c}\text { IS-2386 } \\
\text { Part III }\end{array}$ \\
\hline 6 & $\begin{array}{l}\text { Combined } \\
\text { Elongation } \\
\text { and } \\
\text { Flakiness } \\
\text { Indices }\end{array}$ & $29.0 \%$ & $\begin{array}{l}\text { Not to exceed } \\
30 \%\end{array}$ & $\begin{array}{c}\text { IS-2386 } \\
\text { Part I }\end{array}$ \\
\hline
\end{tabular}


Table-3.4:Properties For Different \% Replacement of RAP with Natural Aggregates

\begin{tabular}{|c|c|c|c|c|c|}
\hline $\begin{array}{c}\text { Sl. } \\
\text { No. }\end{array}$ & Characteristics & $\begin{array}{c}\mathbf{2 5 \%} \\
\text { RAP }\end{array}$ & $\begin{array}{c}\mathbf{5 0 \%} \\
\text { RAP }\end{array}$ & $\begin{array}{c}\mathbf{7 5 \%} \\
\text { RAP }\end{array}$ & $\begin{array}{c}\mathbf{1 0 0} \% \\
\text { RAP }\end{array}$ \\
\hline $\mathbf{1 .}$ & Specific gravity & 2.56 & 2.41 & 2.35 & 2.32 \\
\hline $\mathbf{2 .}$ & Water absorption & $0.45 \%$ & $0.5 \%$ & $0.45 \%$ & $0.4 \%$ \\
\hline $\mathbf{3 .}$ & Crushing Value & $27.9 \%$ & $28.4 \%$ & $28.5 \%$ & $28.9 \%$ \\
\hline $\mathbf{4 .}$ & Abrasion Value & $28.2 \%$ & $28.0 \%$ & $28.7 \%$ & $29.6 \%$ \\
\hline $\mathbf{5 .}$ & Impact Value & $27.9 \%$ & $28.3 \%$ & $29.0 \%$ & $29.1 \%$ \\
\hline & Combined & & & & \\
& $\begin{array}{c}\text { Elongation and } \\
\text { Flakiness Indices }\end{array}$ & $29.1 \%$ & $29.5 \%$ & $30.0 \%$ & $31.0 \%$ \\
\hline
\end{tabular}

Based on these material properties, the Mix Design is prepared for Normal Concrete Mix (NC), Mix 1 (100\% RAP), Mix 2 (75\% RAP), Mix 3 (50\% RAP), Mix 4 (25\% RAP). IRC:44-2008 method is used and the mix proportions and mix details are obtained as follows,

Table-3.6:Mix Details

\begin{tabular}{|c|c|c|c|c|c|}
\hline Mix & NC & 100\%RAP(Mix 1) & 75\% RAP (Mix 2) & 50\% RAP (Mix 3) & 25\% RAP (Mix 4) \\
\hline Water/Cement & 0.38 & 0.38 & 0.38 & 0.38 & 0.38 \\
\hline Cement kg/cum & 425 & 425 & 425 & 425 & 425 \\
\hline FA kg/cum & 667.42 & 667.42 & 667.42 & 667.42 & 667.42 \\
\hline CA type I kg/cum & 652.59 & 0.00 & 140.44 & 288.05 & 458.96 \\
\hline CA type II kg/cum & 533.93 & 0.00 & 114.90 & 235.67 & 375.52 \\
\hline RAP kg/cum & 0.00 & 1008.33 & 766.03 & 523.72 & 278.16 \\
\hline Water kg/cum & 186 & 186 & 186 & 186 & 186 \\
\hline Density of Concrete in kg/cum & 2464.94 & 2286.75 & 2299.79 & 2325.86 & 2391.06 \\
\hline
\end{tabular}

Table-3.7:Number of Specimens Cast

\begin{tabular}{|c|c|c|c|}
\hline NO. & Type of Concrete & Cubes & Beams \\
\hline 1 & Normal Mix (NC) & 12 & 12 \\
\hline 2 & With 100\% RAP (Mix 1) & 12 & 12 \\
\hline 3 & With 75\% RAP (Mix 2) & 12 & 12 \\
\hline 4 & With 50\% RAP (Mix 3) & 12 & 12 \\
\hline 5 & With 25\% RAP (Mix 4) & 12 & 39 \\
\hline
\end{tabular}

Tests adopted for measurement of workability of the concrete mix in the present investigation are,

1. Slump Test, 2. Compacting Factor Test.

2.

Table-3.8: Measurement of Workability

\begin{tabular}{|c|c|c|c|c|c|c|}
\hline $\begin{array}{l}\mathbf{S I} \\
\mathbf{N} \\
\mathbf{O}\end{array}$ & $\begin{array}{l}\text { Name of } \\
\text { the Test }\end{array}$ & $\begin{array}{c}\text { Natural } \\
\text { Aggregat } \\
\text { es (NC) }\end{array}$ & $\begin{array}{c}\mathbf{1 0 0} \\
\% \\
\text { RAP } \\
\text { (Mix } \\
\mathbf{1})\end{array}$ & $\begin{array}{c}75 \\
\% \\
\text { RA } \\
\text { P } \\
\text { (Mi } \\
\times 2)\end{array}$ & $\begin{array}{c}\mathbf{5 0} \\
\% \\
\text { RA } \\
\text { P } \\
\text { (Mi } \\
\text { x 3) }\end{array}$ & $\begin{array}{c}25 \\
\% \\
\text { RA } \\
\text { P } \\
(\mathbf{M i} \\
\text { x 4) }\end{array}$ \\
\hline 1. & $\begin{array}{l}\text { Slump } \\
(\mathrm{mm})\end{array}$ & 35 & 20 & 25 & 32 & 32 \\
\hline 2. & $\begin{array}{l}\text { Compactin } \\
\text { g factor }\end{array}$ & 0.88 & 0.82 & 0.80 & 0.82 & 0.88 \\
\hline
\end{tabular}

Table-3.5: Mix Proportions

\begin{tabular}{|c|l|}
\hline Mix & $\begin{array}{l}\text { Cement: FA: RAP: } \\
\text { Natural Aggregate: Water }\end{array}$ \\
\hline NC (Normal Mix) & 1: 1.57: 0.00: 2.79: 0.38 \\
\hline 100\% RAP (Mix 1) & $1: 1.57: 2.37: 0.00: 0.38$ \\
\hline 75\% RAP (Mix 2) & $1: 1.57: 1.80: 0.60: 0.38$ \\
\hline 50\% RAP (Mix 3) & $1: 1.57: 1.23: 1.23: 0.38$ \\
\hline 25\% RAP (Mix 4) & $1: 1.57: 0.65: 1.96: 0.38$ \\
\hline
\end{tabular}

Cube and beam specimen are cast as per IS: 516-1978. In this process, once the wet concrete mixture is prepared of required standard the concrete is filled in cube moulds $(150 X 150 \times 150 \mathrm{~mm})$ for compressive strength test. For flexural strength the prisms $(500 \times 100 \times 100 \mathrm{~mm})$ were casted. The specimen are removed after 24 hours and immersed in water tank for $1,3,7$ and 28 days. Then the specimen were removed from curing tank and tested immediately under Compression Testing Machine / Flexural Testing Machine. The type and number of specimens cast are as shown in Table 3.7.

\section{RESULTS AND DISCUSSIONS}

\section{Compressive Strength:}

The cube specimens were tested in Compression Testing Machine (CTM) after specified curing period for different percent of RAP replacement $25 \%, 50 \%, 75 \%$, and for normal concrete mix (NC). The compressive strengths after respective curing periods are noted in Table 4.1.

\section{Discussions on Compressive Strength Results:}

Mix 4 is giving maximum strength of $91.84 \%$ of $\mathrm{NC}$ strength, $45 \mathrm{~N} / \mathrm{mm}^{2}$ which is very nearer to Normal Concrete Mix Strength for 28 days curing period. And also Mix 4 is showing good early strength of $17 \mathrm{~N} / \mathrm{mm}^{2}$ for 1 day curing period, which is of $85 \%$ of strength gain with respect to NC Mix.

Table-4.1:Compressive Strength Results

\begin{tabular}{|c|c|c|c|c|}
\hline \multirow{2}{*}{ Composition } & \multicolumn{4}{|c|}{ Compressive Strength in N/mm } \\
\cline { 2 - 5 } & 1 day & $\mathbf{3}$ days & $\mathbf{7}$ days & $\mathbf{2 8}$ days \\
\hline NC & 20 & 25 & 32 & 49 \\
\hline $100 \%$ RAP (MIX 1) & 9 & 15 & 21 & 35 \\
\hline $75 \%$ RAP (MIX 2) & 10 & 15 & 22 & 36 \\
\hline $50 \%$ RAP (MIX 3) & 12 & 17 & 26 & 39 \\
\hline $25 \%$ RAP (MIX 4) & 17 & 23 & 29 & 45 \\
\hline
\end{tabular}




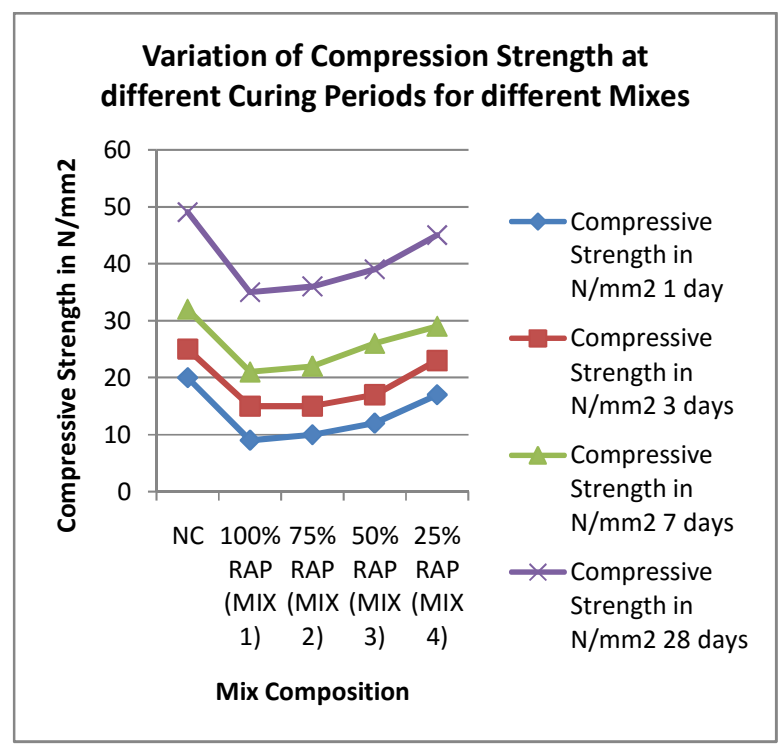

Fig-4.1:Graph showing Compressive Strength Development of Different Mixes

\section{Flexural Strength:}

The specimens were tested in flexural testing machine as given in Annexure $\mathrm{V}$ and the flexural strength is calculated depending on the failure plane position from the supports. Values obtained for concrete with different RAP replacement levels and for the normal concrete mix (NC) are as note in Table 4.2.

Table-4.2:Flexural Strength Results

\begin{tabular}{|c|c|c|c|c|}
\hline \multirow{2}{*}{ Composition } & \multicolumn{5}{|c|}{ Flexural Strength in $\mathbf{N} / \mathbf{m m}^{\mathbf{2}}$} \\
\cline { 2 - 5 } & 1 day & 3 days & $\mathbf{7}$ days & $\mathbf{2 8}$ days \\
\hline NC & 2.9 & 3.2 & 3.7 & 4.5 \\
\hline 100\% RAP (MIX 1) & 0.9 & 1.1 & 1.9 & 2.8 \\
\hline $75 \%$ RAP (MIX 2) & 1.6 & 1.9 & 2.2 & 3.2 \\
\hline $50 \%$ RAP (MIX 3) & 2.0 & 2.2 & 2.9 & 3.7 \\
\hline 25\% RAP (MIX 4) & 2.6 & 3.0 & 3.2 & 4.1 \\
\hline
\end{tabular}

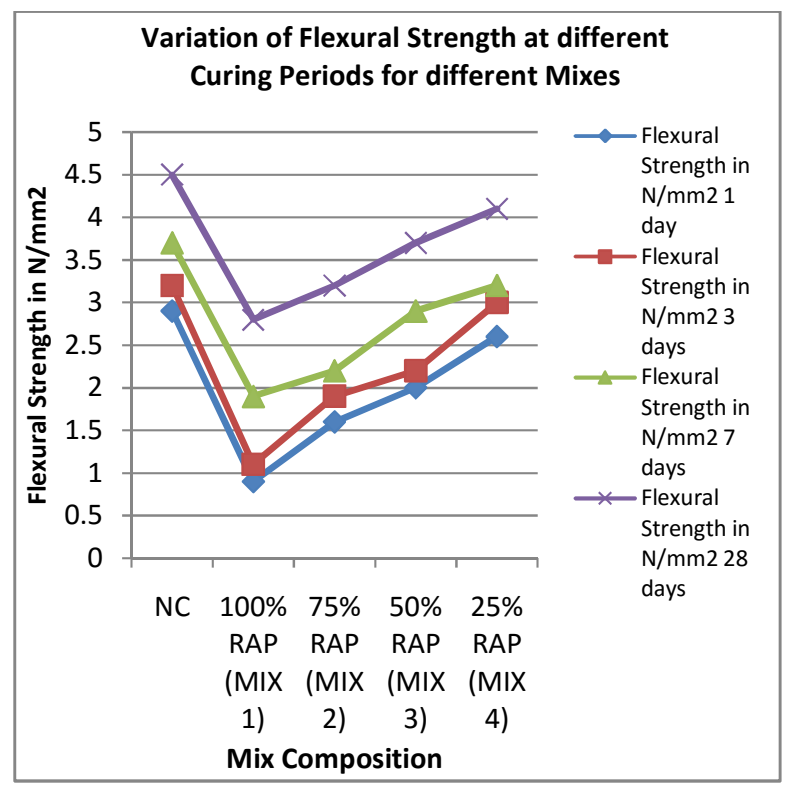

Fig-4.2: Graph showing Flexural Strength Development of Different Mixes

\section{Discussions on Flexural Strength Results:}

From the test results of flexural strength, it is observed that NC shows higher flexural strength compared to different RAP replacement levels. Mix 4 shows higher flexural strength of $4.1 \mathrm{~N} / \mathrm{mm}^{2}$ for 28 days curing period, which is very nearer $(91.11 \%$ of NC Strength) to strength of Normal Concrete $\left(4.5 \mathrm{~N} / \mathrm{mm}^{2}\right)$.

\section{DEVELOPMENT OF FATIGUE MODELS}

In the present investigations, the flexural fatigue tests are done on Mix Concrete with 25\% RAP and 75\% Natural Aggregates (Mix 4). The prism specimens are of size $500 \times 100 \times 100 \mathrm{~mm}$, are subjected to accelerated half sine wave form of cyclic loading tests at three stress levels $65 \%$, $75 \%$ and $85 \%$ of static flexure load $(9.957 \mathrm{KN})$. Results got by the Static Flexural Strength Test is considered for deciding the load to be applied, with a rest period of $1 \mathrm{sec}$ and frequency of load application being $2 \mathrm{~Hz}$ i.e., two cycles per second. Prediction of fatigue life using statistical model is attempted for Log Normal Distribution (Linear Regression Analysis).

The beam specimens are marked in the same way as for the static flexure test. The load cell is brought in contact with the loading frame placed on the specimen. The computer system and other instrumentations are kept ready. Specimen is marked with a chalk/pencil. The support points at $400 \mathrm{~mm}$ apart from the bottom and $133.33 \mathrm{~mm}$ from the top. The load is then applied on the frame by giving data entries in the computer.

The number of repetitions to failure of specimen at different stress levels is given in Table 5.1. For convenience in the development of fatigue models the results have been arranged in an ascending order.

Table-5.1:Number of Repetitions for Failure of Specimen of Mix 4

\begin{tabular}{|c|c|c|c|}
\hline Specimen & \multicolumn{3}{|c|}{ No. of Repetitions to Failure } \\
\hline & SR=0.65 & SR=0.75 & SR=0.85 \\
\hline $\mathbf{1 .}$ & 101 & 23 & 10 \\
\hline $\mathbf{2 .}$ & 502 & 543 & 290 \\
\hline $\mathbf{3 .}$ & 2449 & 2345 & 987 \\
\hline $\mathbf{4 .}$ & 9989 & 3567 & 2330 \\
\hline $\mathbf{5 .}$ & 11120 & 6990 & 5559 \\
\hline $\mathbf{6 .}$ & 12430 & 8990 & 8932 \\
\hline $\mathbf{7 .}$ & 15988 & 12343 & 9855 \\
\hline $\mathbf{8 .}$ & 17495 & 15670 & 12391 \\
\hline $\mathbf{9 .}$ & 21001 & 19322 & 16890 \\
\hline
\end{tabular}




\section{Log Normal Distribution Model:}

A Log Normal Distribution model which is also a Linear Regression Model of the form $(\mathrm{Y}=\mathrm{aX}+\mathrm{b})$ is attempted using present experimental results in which stress ratio (SR) is taken on $\mathrm{Y}$-axis and $\log (\mathrm{N})$ values are taken on $\mathrm{X}$-axis. The scatter diagram and the linear relationship have been shown in Figure 4.2.1. The Linear Regression Model considering all the values are given by Equation, $\mathbf{y}=$ $0.0148 x+0.8016$

With $\mathrm{R}^{2}=0.0260, \mathrm{R}^{2}$ being the Regression Co-Efficient

In this case, $y=S$, the stress ratio and $x=\log N$. Then the equation becomes-

$\log \mathbf{N}=\frac{0.8016-S R}{0.0148}$

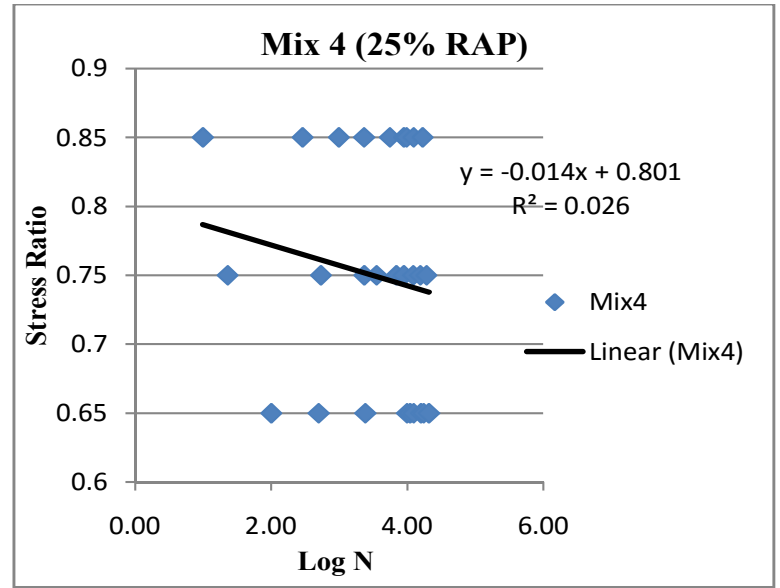

Fig-5.1:Scatter Diagram \& Linear Relationship for Mix 4

From the results obtained for 9 specimens in the Linear Regression Model shown above, the $\mathrm{R}^{2}$ value obtained is 0.0260 which clearly shows that there is a lot of scatter among the number of repetitions. Applying the correction by omitting lowest values, Linear Regression model considering 6 specimens per stress ratio is developed. The corrected model is shown in Equation below and the relation is shown in Figure 5.2.

$\mathbf{y}=\mathbf{- 0 . 1 3 9 7} \mathbf{x}+\mathbf{1 . 3 1 0 4}$ With $\mathrm{R}^{2}=0.1783$

$\log \mathbf{N}=\frac{1.3104-S R}{0.1397}$

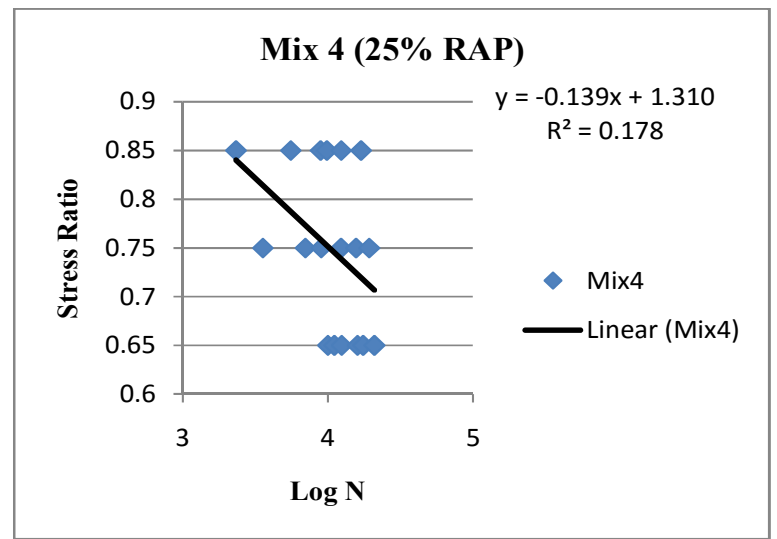

Fig-5.2: Scatter Diagram \& Linear Relationship for Mix 4 with Omitted Values

\section{Fatigue Equation as Per IRC: 58-2011:}

The Fatigue Equation given by IRC: 58 - 2011 code is used to compare the developed linear regression model for Mix 4. The models suggested by IRC when SR $>0.55$ is, $\log _{10} \mathbf{N}=$ $\frac{0.9718-S R}{0.0828}$

Similarly for Mix 4 with SR being $>0.55$, the equation becomes, $\log _{10} \mathbf{N}=\frac{1.3104-S R}{0.1397}$

All test data for PQC is used to compare the number of repetitions to failure with IRC model. The comparison is shown in Table 5.2 and Figure 5.3.

Table-5.2:Comparison of No. of Repetitions to Failure of both the Models

\begin{tabular}{|c|c|c|}
\hline \multirow{2}{*}{ SR } & \multicolumn{2}{|c|}{ No. of Repetitions to Failure } \\
\cline { 2 - 3 } & IRC & Mix 4 (25\% RAP) \\
\hline $\mathbf{0 . 5 5}$ & 124223 & 277390 \\
\hline $\mathbf{0 . 6}$ & 30927 & 121669 \\
\hline $\mathbf{0 . 6 5}$ & 7699 & 53367 \\
\hline $\mathbf{0 . 7}$ & 1917 & 23408 \\
\hline $\mathbf{0 . 7 5}$ & 477 & 10267 \\
\hline $\mathbf{0 . 8}$ & 119 & 4503 \\
\hline $\mathbf{0 . 8 5}$ & 29 & 1975 \\
\hline
\end{tabular}

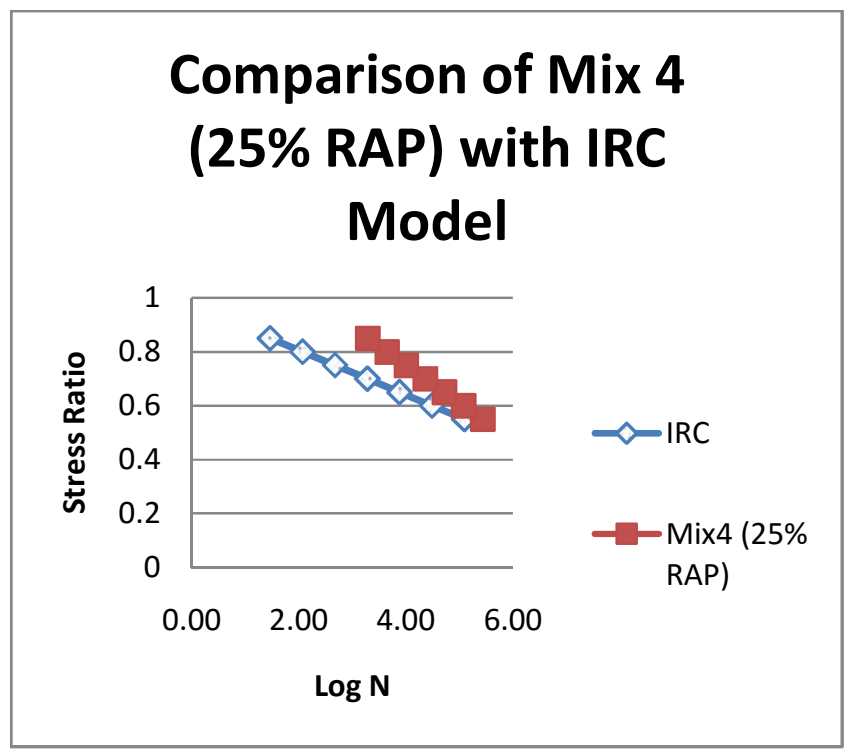

Fig-5.3:Comparison of Mix 4 (25\% RAP) with IRC Model

From the analysis on the corrected results, it is evident that $\mathrm{R}^{2}$ value has increased to 0.1783 . Even though this value is less, we can conclude that scatter among the number of repetitions is comparatively less. Otherwise we can go for Weibull Distribution or Chi-Square Distribution to develop a Fatigue Model. 


\section{CONCLUSIONS}

1. Replacement of $25 \%$ RAP (Mix-4) gives maximum compressive strength comparatively than other replacement percentages (About $91 \%$ of NC Strength).

2. Reference mix shows maximum flexural strength more than the RAP replaced mixes. But the Mix- 4 , i.e. $25 \%$ RAP replacement is giving strength very nearer to that of NC.

3. The number of repetitions to failure obtained for Mix 4 is less than IRC (reference mix NC) up to 0.85 stress ratio. But still RAP replaced concrete can be used for pavements; in particular it is recommended for low traffic volume roads.

4. The supporting factors to justify the use of RAP Mix are,

a. Easy to remove flexible pavement and use its material for placing of concrete pavement. Thus reducing transportation cost and cost of natural aggregates.

b. Use of RAP aggregate also reduces the burden on natural course aggregate for increasing aggregate demand for construction of roads.

c. It helps to reduce environmental imbalances and pollution while removing natural aggregate in quarry.

\section{REFERENCES}

[1] Delwar, M., Fahmy, M., \&Taha, R. (1997),Use of Reclaimed Asphalt Pavement as an Aggregate in Portland Cement Concrete. ACI Materials Journal (May - June 1997), 251-256.

[2] Huang, B., Shu, X., \& Li, G. (2005), Laboratory Investigation of Portland Cement Concrete Containing Recycled Asphalt Pavements. Cement and Concrete Research , 2008-2013.

[3] Huang, B., \&Shu, X. (2005),Experimental Study on Properties of Portland Cement Concrete Containing Recycled Asphalt Pavements. Innovations for Concrete Pavement: Technology Transfer for the Next Generation (pp. 485-499). Colorado Springs: International Society for Concrete Pavements.

[4] Hossiney, N. J. (2008), Evaluation of Concrete Containing RAP for use in Concrete Pavement, Civil Engineering, Gainesville: University of Florida.

[5] Concrete Technology (Theory and Practices) by M.S. SHETTY. S.Chand\& Company Pvt.Ltd Publications.

[6] Highway Engineering by S.K.Khanna and C.E.G.Justo, Nem Chand \& Bros, Roorkee,U.K.,India (Ninth Edition 2011).

[7] Principles and Practices of Highway Engineering - by Dr. L R Kadyali, Dr. N B Lal.

[8] IRC: 15-2011, Standard Specifications and code of practice for Construction ofConcrete Roads, $4^{\text {th }}$ Revision, Indian Roads Congress, New Delhi.

[9] IRC: 44-2011, Guidelines for cement concrete mix design for pavements, IndianRoads Congress, New Delhi.

[10] IS: 10262-2009, Indian Standard CONCRETE MIX PROPORTIONING -GUIDELINE (First Revision).

[11] IS: 2386(Part I -1963), Particle size and shape, Bureau of Indian Standards, NewDelhi.

[12] IS: 2386(Part III-1963), Specific gravity, density, voids ,adsorption and bulking,Bureau of Indian Standards, New Delhi. 